\title{
IT and Legal Education in the Future
}

\author{
by Professor Richard Susskind
}

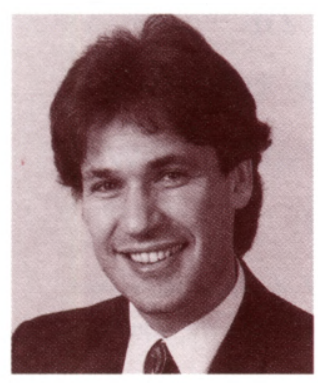

Richard Susskind believes that if UK lawyers are to compete internationally, it is axiomatic that they should have a far greater expertise in IT, gained throughout their careers from a blend of education, training and awareness raising.

\section{I} n 1990, I visited the Washington office of a law firm widely recognised to be one of the most advanced and committed users of technology in the American legal community. The director of IT talked a lot about the culture that they had managed to engender within the firm. Here certainly was an atmosphere within which IT could flourish. By way of illustration, she recalled a telephone conversation that she had had that very morning, a chat with a new recruit fresh from law school. That individual had called to say that there seemed to have been some kind of mistake: there was no machine on his desk awaiting his arrival.

\section{UK LAWYERS LAG BEHIND}

I reflected, with some irony, that in the UK it would be more likely that a fresh trainee solicitor would contact the computer support department to indicate that there had been some kind of error only if a machine was indeed on his desk on arrival. Were it not so amusing, we would all immediately see this as tragic. Here, no doubt, is one reason why the US legal profession may have years of strategic competitive advantage over UK lawyers - their students are more comfortable with IT.

It is said that over $80 \%$ of US law students have their own machines. I do not know if anyone has had the nerve to survey the UK position but I would hazard a guess, from my travels and chats to colleagues in the academic community, that less than $10 \%$ of British undergraduates have computers they could call their own. So, although it is commonly conjectured that the lack of IT uptake by UK lawyers is but a short term concern, merely a blip because all law graduates today have surely been using technology while at university, this is almost certainly not so. In fact, few law schools in universities in the UK provide adequate encouragement and training in IT today, and even those that do are often regarded as idiosyncratic, hobbyist or indulgent.

\section{IT AS A DISTINCT DISCIPLINE?}

Although each phase in the legal career requires and deserves a different educational perspective and approach to IT - my model is outlined in this paper - there is a fundamental theme common to all phases, which I deal with first of all. It relates to the temptation to treat IT as a distinct discipline.
There are many ways in which law students and legal practitioners can learn about IT: for example, by relatively formal, conventional education; or by on-the-job training; or through awareness raising exercises. Whichever method is chosen, it is wrongheaded, in my view, to regard IT as a distinct discipline and something which should be taught as though it were a separate legal subject. To hold IT out as an entirely independent field is almost as misleading as identifying reading or writing for lawyers as distinct disciplines in their own right.

Instead, if the power of technology is to be exploited by the profession, IT should be projected as something that is an integral part of the way we research into the law, learn about new legal developments, advise our clients and provide them with information.

To insist on separating IT from how it is applied, for the purposes of education and teaching is, at best, to miss the opportunity to be exposed to practical, everyday uses of technology. At worst, it perpetuates a legal mind-set dominated by print and paper, with technology available only for those who feel so inclined or interested; rather than recognising it to be indispensable for the legal profession of the future. The paper and print mentality will have no place in an IT-based information society in which, for example, there will be hundreds of millions of people on the Internet. Lawyers must be trained to work digitally in a digital world or they may as well shut up shop tomorrow.

\section{IT IN SCHOOLS}

During the past few years, in the context of my own children's schooling, I have had cause to visit a large number of primary and secondary schools and have quite naturally inquired about the extent to which IT plays a part in the lives of pupils. As one might expect, I found varying degrees of commitment and interest. Generally, however, I was surprised and refreshed by the level of enthusiasm and support. The result is that most tenyear-olds today have more 'flying hours', as it were, than adults over 50. It is fair to conclude that our schools are increasingly producing students who are comfortable with computers and telecommunications and for whom the regular use of IT in learning is the norm. 
The National Curriculum for UK schooling unambiguously endorses the relevance of IT for the education of our young and indeed requires programmes of study and attainment targets for IT throughout the school career. Rightly, in my view, there is emphasis on the use of IT in practical situations and on appreciation of its impact on the workplace and society. It would surely be scandalous if this solid foundation created during schooling were to be followed by a dip in exposure to IT for all university students when they progress to legal undergraduate studies. Sadly, in the already overcrowded curricula of most university law faculties, some legal academics have become exasperated with the thought of having to introduce one further subject, in the shape of IT, even though most do recognise its significance.

\section{UNDERGRADUATE IT}

In the past, when it was thought appropriate to teach a separate course with some such title as Computers for Lawyers, those law faculties which made such a module compulsory certainly found it eating into the core legal subjects of an already packed curriculum. But those who took the alternative route, making such a course optional, found that they were attracting only the eccentrics and the enthusiasts, those who were already committed to and interested in IT. In contrast, in the latter scenario, the mainstream law student regarded the whole subject as peripheral and tended to take a raincheck on technology.

In retrospect, this was something of a nebulous dilemma, in that the future careers of these students should not have demanded any detailed knowledge of computing and telecommunications. Instead, creating a comfortable disposition towards technology and a familiarity with its impact on practical tasks would have had a more lasting and useful impact.

\section{A CENTRAL TOOL}

This positive disposition towards IT can be achieved in large part by using IT in actually teaching and learning about the law. This can help to highlight the relevance of technology, to illustrate its practical relevance and bring its usage to the heart of legal understanding. Moreover, encouraging students to use technology in studying the law - whether in writing essays using word processors, using retrieval systems to undertake legal research, or communication systems to download external information - exposes law students to benefits and results, rather than abstract information about, say, the architecture of computer hardware or the basics of computer programming. Law students who have experienced IT as a teaching tool and a mechanism for generating their own work product, are well placed to progress to the next stage of their technical education.

Law tutors and lecturers should not aspire to any technical detail in their treatment of IT. They must forget about programming, operating systems, fifth generation architectures and the like and instead instil an attitude which has for long been inculcated into students of the applied sciences. Law students should therefore be like undergraduate engineers, or nuclear physicists, who quite naturally turn to IT and take it on board as an invaluable tool which supports the pursuit of their core disciplines.

Thus, significant parts of the legal curriculum should be delivered through electronic law tutorials, computer-based law 'courseware', computer-assisted learning or computer-assisted instruction (known respectively, in the UK and USA, as CAL and CAI).

Distance learning should also gain acceptance, following the lead of law schools such as that of Strathclyde University, from which an LLM in Legal Informatics is being taken by students all over the world, who are given remote access to 25 megabytes of teaching material and participate in on-line, group tutorials.

Above all else, our law schools must avoid the temptation to transfer responsibility for teaching IT to those who preside over later stages in the educational process. 'It's best to wait and see how your future employer will want you to use IT' is rationalisation of an unhelpful variety. Claims that the proper place for IT education for lawyers should be during law school, bar school or training contracts constitute unacceptable abdication of responsibility. It is not just that we now live in a world where missing out on IT for three or four years is folly (although this is certainly so), it is that the teaching of law in the absence of IT is gradually becoming a misrepresentation of legal practice and legal process.

\section{FUNDING PROBLEMS}

Those academic lawyers who have accepted all of this have been confronted, however, by the very practical problem that UK law schools are severely underfunded for IT. The current level of government support still seems to be based on law students requiring little more than book-based library services rather than the IT-based information services to which some law schools are rightly now aspiring. As a matter of urgency, a high profile, coherent case must be made by the academic legal community, with the support of the professional bodies, to the various state funding authorities. This should show the law undergraduates' need for laboratory resources is now akin in many ways to the requirements of students of, say, the natural sciences, and that a minimum technology capability is as crucial as an agreed baseline for conventional library holdings. The appeal for more funding can be tempered, however, by savings which commitment to IT will bring, for example, in providing access to a vast, 'virtual' law library across the world which should make some materials available without needing to be purchased in the conventional manner.

But I do not underestimate the challenge here in times when increase in public funding for universities seems to be anathema to the prevailing government ethos. The topic also raises many other fundamental issues about academic lawyering, not least of which is the related need, in my view, for work on the development of appropriate, legal information systems to be recognised as worthy academic research and accredited with the same status as conventional publications.

\section{PROFESSIONAL EXAMINATIONS}

Once students have graduated and progressed to their professional examinations (legal practice courses for solicitors and bar school for barristers) the impetus should be maintained. The emphasis here should be less on tutoring systems and applications for student work, and more on the kinds of technologies to which these individuals are likely to be exposed when they enter their chosen branch of the profession. With their strong accent on the law in action and practical lawyering, these courses must pay more than lip service to technology, if 
the insights and experience gained as legal undergraduates are not to be lost. Again technology should be portrayed as a feature of legal practice and not a discipline in its own right.

In this context I have been asked by various institutions to suggest a checklist of software packages to which the law student should be exposed during their professional studies. To be concerned about packages, however, is of little assistance and limits users' thinking and perspective. The emphasis should instead be at the level of applications (for example, litigation support or electronic communications) rather than enabling techniques and particular software packages.

\section{RECRUITING POLICIES}

It has also been put to me by providers of legal practice courses that no law firms in England have yet expressed a preference for recruiting individuals with experience of IT; and so they have said they have little encouragement to cover IT. This problem is a circular one, however, because very few firms are themselves motivated by having actually reaped the benefits of genuinely and thoroughly IT-educated law graduates who from the very start of their traineeships can add value. In fact, most firms are not yet themselves suitably placed, in any event, to take advantage of the experience which IT-literate trainees may have to offer. Until legal practices have invested in front and client office systems, they are unlikely to see the relevance of junior staff using IT. When they have such systems in place and have some experience of how trainees can contribute, I suspect firms will then clamour for more and the level of demand may shift. For now, the imaginative course providers should see that exposing their students to appropriate IT is likely to help hasten the general uptake across the profession and, in due course, to increase the interest they feel is lacking today.

\section{INITIAL TRAINING}

Once these graduates progress to law offices or chambers, one would hope that they would be expecting that IT will be at their disposal during the course of their traineeships or pupillages, as the case may be. Here again, the early investment in training must continually be topped up and many young lawyers have been rather disillusioned to find that otherwise seasoned practitioners either ignore technology altogether or use their machines for a very narrow set of purposes. They have been miffed even more when told that they do not get machines for their own use until they qualify some two years later. Once more continuity is vital; there should be no period during which the trainee or pupil barrister should be without access to a computer

Optimistically, trainee lawyers can, as I have said, be a major source of impetus for IT within an organisation and there is an opportunity here for their own experience and understanding to be passed on to their senior colleagues.

Realistically however, it cannot yet be assumed automatically that younger lawyers are more sympathetic and enthusiastic about new technologies than their more senior colleagues. In practice I have not found this to be the case. Indeed, my most receptive audiences tend to be the most senior of lawyers and judges who contrast markedly with many recently qualified lawyers who are prone to being cynical and rather closedminded about IT. This is a temporary phenomenon, however, because this prevailing attitude today is probably a function of an
IT-free earlier legal education which has not prepared them for the use of IT.

\section{ONGOING EXPOSURE}

Perhaps the most challenging of all aspects of IT education for lawyers is the provision of training to well-established senior practitioners who have never been taught about IT and whose awareness is low. While many such lawyers hope that they can hold out until retirement, without having to immerse themselves in technology, the challenge for management in firms is to create an environment in which keeping up to date with IT is as natural as monitoring legal developments.

One-to-one training in the comfort, security and seclusion of lawyers' own offices works very well, and avoids the inhibitions and embarrassments which may arise for senior colleagues in group training sessions. Moreover, for the busy practising lawyer, there seems to be no better way of introducing new technologies than to have the trainer introduce applications in the context of live work which the lawyer is currently progressing. On one model, the trainer asks the lawyer what tasks he has before him for the day and then they work together in completing these tasks. It may be drafting a letter, for example, in which case they will use the computer and prepare the communication from beginning to end.

In this way, technology training for lawyers should focus on the accomplishment of tasks and the achievement of results rather than running a lawyer through the features of particular packages or describing the various capabilitics of some system. Lawyers, like all users, absorb more from training when it is provided in the context of everyday work and not when it is served up in a vacuum of technical chit-chat. Lawyers need to see IT in action. They must learn about text entry (by keyboard or voice), hypertext browsing, project management and electronic communication by seeing it work in familiar surroundings and in relation to their specific work loads.

Looking beyond basic training, an enduring dilemma is whether to be paternalistic or libertarian in helping lawyers to make the most of their investment on a day-to-day basis. The paternalists commit to spoon feeding and continually seek to top up their users' IT know-how. The libertarians let their lawyers explore for themselves and encourage self reliance and a working environment in which IT will flourish without training programmes. The reality is that some lawyers react well to one approach and others favour the opposite. In an organisation of size, both approaches must be adopted if widespread and successful exploitation is to be achieved. Only then will all lawyers in the entire work force gradually see themselves as information managers in the business of information processing. They will also come to feel comfortable with the notion of providing information services and not just advice. Ultimately, they will want IT to work for them.

Professor Richard Susskind DPhil (Oxon) LLB (Glas) FBCS FRSE

Centre for Law, Computers and Technology, University of Strathclyde The arguments in this paper are derived largely from the author's book, The Future of Law (Oxford University Press, 1996) 